\title{
The epidemiological profile of Pediatric Intensive Care Center at Hospital Israelita Albert Einstein
}

\author{
O perfil epidemiológico do Centro de Terapia Intensiva Pediátrico do \\ Hospital Israelita Albert Einstein
}

\author{
Camila Sanches Lanetzki ${ }^{1}$, Carlos Augusto Cardim de Oliveira ${ }^{2}$, Lital Moro Bass ${ }^{3}$, \\ Sulim Abramovici ${ }^{4}$, Eduardo Juan Troster ${ }^{5}$
}

\begin{abstract}
Objective: This study outlined the epidemiological profiles of patients who were admitted to the Pediatric Intensive Care Center at Albert Einstein Israelite Hospital during 2009. Methods: Data were retrospectively collected for all patients admitted to the PICC during 2009. A total of 433 medical charts were reviewed, and these data were extracted using the DATAMARTS System and analyzed using the statistical software package STATA, version 11.0. Results: There were no statistically significant differences in regards to patient gender, and the predominant age group consisted of patients between the ages of 1 to 4 years. The average occupancy rate was $69.3 \%$ per year, and there was a greater number of admissions during April, August, and October. The average length of stay at the hospital ranged from 9.7 to 19.1 days. Respiratory diseases were the main cause for admission to the Pediatric Intensive Care Center, and the mortality rate of the patients admitted was $1.85 \%$. Conclusions: Respiratory diseases were the most common ailment among patients admitted to the Pediatric Intensive Care Center, and the highest mortality rates were associated with neoplastic diseases.
\end{abstract}

Keywords: Patient admission; Intensive care units; Child; Intensive care, neonatal; Epidemiology, descriptive; Health profile

\section{RESUMO}

Objetivo: Traçar o perfil epidemiológico de pacientes admitidos no Centro de Terapia Intensiva Pediátrico do Hospital Israelita Albert Einstein no período de 1 ano. Métodos: 0 s dados foram coletados retrospectivamente de todos pacientes admitidos no Centro de Terapia Intensiva Pediátrico durante 0 ano de 2009. A extração dos dados contidos nos 433 prontuários revisados foi realizada do sistema DATAMARTS e analisada com o programa estatístico STATA, versão 11. Resultados: Não houve diferença significativa para gênero, e a faixa etária predominante foi de 1 a 4 anos. A média de ocupação foi de $69,3 \%$ ao ano com maior fluxo nos meses de abril, agosto e outubro. A média de permanência variou de 9,7 a 19,1 dias. As doenças respiratórias foram responsáveis pelo maior número de pacientes no Centro de Terapia Intensiva Pediátrico e a taxa de mortalidade foi de 1,85\%. Conclusões: As doenças respiratórias foram as mais frequentes e a maior taxa de mortalidade esteve associada a doenças neoplásicas.

Descritores: Admissão do paciente; Unidades de terapia intensiva; Criança; Terapia intensiva neonatal; Epidemiologia descritiva; Perfil de saúde

\section{INTRODUCTION}

Epidemiological studies are generally conducted to examine disease processes that affect a family member, a friend, or a patient ${ }^{(1)}$. Historically, the field of epidemiology was based on the study of major epidemics, which remain a major threat to health and human life ${ }^{(1)}$.

Descriptive epidemiology is focused on identifying and reporting the pattern and frequency of events related to the health of a population, and this process

\footnotetext{
Study carried out at Hospital Israelita Albert Einstein - HIAE, São Paulo (SP), Brazil.

${ }^{1}$ Residency Program, Hospital Israelita Albert Einstein - HIAE, São Paulo (SP), Brazil.

${ }^{2}$ Faculdade de Medicina da Univille - Joinville (SC), Brazil; Course on Emergency Pediatrics, Hospital Israelita Albert Einstein - HIAE, São Paulo (SP), Brazil.

${ }^{3}$ Hospital Israelita Albert Einstein - HIAE, São Paulo (SP), Brazil.

${ }^{4}$ Hospital Dr. Moysés Deutsch - São Paulo (SP), Brazil.

${ }^{5}$ Hospital Israelita Albert Einstein - HIAE, São Paulo (SP), Brazil; Instituto de Tratamento de Câncer Infantil - São Paulo (SP), Brazil.

Corresponding author: Camila Sanches Lanetzki - Rua Lucrécia Maciel, 236, apto. 93 - Vila Guarani - Zip code: 04314-130 - São Paulo (SP), Brazil - Phone: (11) 3853-9378 - E-mail: cslanetzki@hotmail.com Received on: Feb 6, 2011 - Accepted on: Oct 20, 2011
}

Conflicts of interest: None 
aims to determine the general characteristics of disease behavior and identify the most vulnerable population subgroups ${ }^{(1-5)}$. To understand the health and disease patterns of a population group, data regarding the affected individuals and the duration and location of the disease are required ${ }^{(1-5)}$. For example, Lilienfeld has stated that "the epidemiologist is primarily interested in disease incidence according to the time, place, and people involved. The epidemiologist determines whether there has been an increase or decrease in disease incidence over time, whether a specific geographical area has a higher disease frequency than others, and whether the characteristics or clinical conditions of the individuals affected by the disease differ from those of individuals not affected by the disease"(5).

Knowledge of epidemiological reports concerning the morbidity and mortality of a health care unit can assist in strategic decisions aimed at improving patient quality of care. The acquisition of technologies, training of human resources, and re-evaluation of care processes, in addition to structural reorganization, can be employed according to the demographic characteristics and morbidity of the population. These data enable prospective comparisons to be made with benchmark standards and similar health care units, including regional and international units, as well as within the same unit, for the continuous pursuit of providing quality health care.

From 2006 to 2009, there was a progressive decrease in the number of deaths worldwide in children under 1 year of age. During this time, the highest mortality rates were recorded in Angola and Sierra Leone, and the lowest rates were observed in Japan, Sweden, and Singapore ${ }^{(6)}$.

Due to the lack of epidemiological data from pediatric intensive care units (PICUs), there have been efforts to systematically and reliably collect these types of data. For example, the Paediatric Intensive Care Society in the United Kingdom (UK) created the Annual Report of the Paediatric Intensive Care Audit Network (PICANet) in 2002. PICANet is a database that includes the detailed records of treatments provided to all critically ill children admitted to intensive care units (ICUs) in the UK. These records indicated that more than 49,000 children between the ages of 0 and 15 years of age received pediatric intensive care in the UK from 2007 to 2009. Moreover, records from the 28 National Health Service (NHS) units reported the following statistics: 1) $60 \%$ of the hospitalizations were unplanned emergencies; 2) approximately half of the patients were under 1 year of age $(47 \%) ; 3)$ the majority of patients were male (56\%); and 4) $64 \%$ of the patients required respiratory support ${ }^{(7)}$.

Few epidemiological surveys have been performed in PICUs in Brazil. However, the study by Cutulo et al. reviewed the medical charts of 402 patients who were admitted to ICUs at the Joana de Gusmão Hospital in Florianópolis (SC, Brazil) in 1993. This study found that the average age at the time of admission was 17.5 months, that $55.7 \%$ of the patients were male, and that the most common causes of hospitalization included respiratory conditions, injuries, poisoning, and gastrointestinal disease. Moreover, the complications that resulted in the highest rates of mortality included shock, sepsis, and respiratory insufficiency ${ }^{(8)}$.

In addition, a study by Alves et al. studied the profiles of 1,186 children consecutively admitted to the PICU at a university hospital in Brazil from 1990 to 1994. These authors found the mortality rate to be $14.2 \%$ and the median age of the patients to be 11 months. Using the Pediatric Risk of Mortality (PRISM) predictive scores, this study demonstrated that the care provided by the PICU was adequate as compared to that delivered by other PICUs ${ }^{(9)}$.

A study by Einloft et al. reviewed the epidemiological data of 13,101 patients admitted to a pediatric care unit in Brazil from 1978 to 1994. These authors found that the patients were mostly male (58.4\%), $40.4 \%$ of the patients were younger than 1 year of age and that $30 \%$ of the patients demonstrated evidence of malnutrition. The overall mortality rate of the patients in this study was $7.4 \%$; patients younger than 12 months of age were approximately twice as likely to succumb to their condition than the average of all patients, and malnourished patients were three times more likely to die during their hospital stay. In this study, the most common cause of death was sepsis ${ }^{(10)}$.

\section{OBJECTIVE}

This study sought to describe the demographic characteristics, diagnoses, and clinical outcomes of patients who were admitted to the Pediatric Intensive Care Center (PICC) at Albert Einstein Israelite Hospital (HIAE) in 2009.

\section{METHODS}

This retrospective study was conducted using data collected from the medical charts of patients who were admitted to the PICC at HIAE in 2009.

The PICC provides health care for children between the ages of 0 to 18 years who are covered through health care plans, private funding, or philanthropy. The PICC offers clinical and surgical care in every specialty, including trauma and burn care. The unit is equipped with 7 Servo ${ }^{\circledR}$ ventilators (invasive ventilation), 2 BiPAP Vision ${ }^{\circledR}$ ventilators (noninvasive ventilators), 9 
multi-parameter monitors, and 1 monitor for central venous saturation. The PICC has a clinical staff consisting of 11 doctors, 1 manager, 1 locum, 9 on-call physicians, 2 nurses and either 1 nurse technician for every two patients or 1 nurse technician for every patient in highly complex cases. In addition, the PICC has a multidisciplinary team composed of physiotherapists who are specialized in respiration and motor function, nutritionists, and psychologists. The PICC offers a concurrent educational program for second-year residents in General Pediatrics and graduate students enrolled in the pediatric emergencies course.

Data were collected from all 433 inpatients at HIAE during 2009 using the DATAMARTS system. The following variables were included for analysis: operating capacity (occupancy rate and number of beds); age; gender; reason for hospitalization (clinical, surgical, transplant, or emergency); length of stay; reason for discharge (death, medical discharge, internal transfer, or discharge by request); and diagnosis (ICD10). The cause of death was obtained from the death certificate of each patient.

The data were analyzed using the statistical software package STATA, version 11.0 (StataCorp LP, College Station, Texas, USA). The $\chi^{2}$ test was used to compare proportions of patients, and Student's $t$-test was used to compare the independent sample means. To estimate the random errors, a cut-off point of $5 \%$ was established for the acceptance or rejection of the null hypothesis.

\section{RESULTS}

In 2009, the PICC consisted of 9 beds, and the average occupancy rate was $69.33 \pm 11.58 \%$. The average annual occupancy was 6.1 patients/day. The months with the lowest volume of admissions were March and November, and the months with the greatest number of admissions were April, August, and October.

Of the 433 patients analyzed, $237(54.73 \%)$ were male. The average and median ages of the patients were 4.9 and 2.7 years, respectively. There were no statistically significant differences in the mean ages between the two genders; the mean age of the male patients was 4.6 years, and the mean age of the female patients was 5.3 years $(p=0.144)$. The age distribution of the patients according to frequency is shown in figure 1.

The average length of stay at the hospital was 9.7 days, ranging from 1 to 176 days, and half of all patients remained in the unit for 4 days or less. There were no statistically significant differences in the mean lengths of stay according to gender (female: 9.03 days; male: 10.23 days; $p=0.51$ ) or age (neonatal, infants, early or late childhood; $p=0.416$ ). Among the 28 patients who remained admitted for more

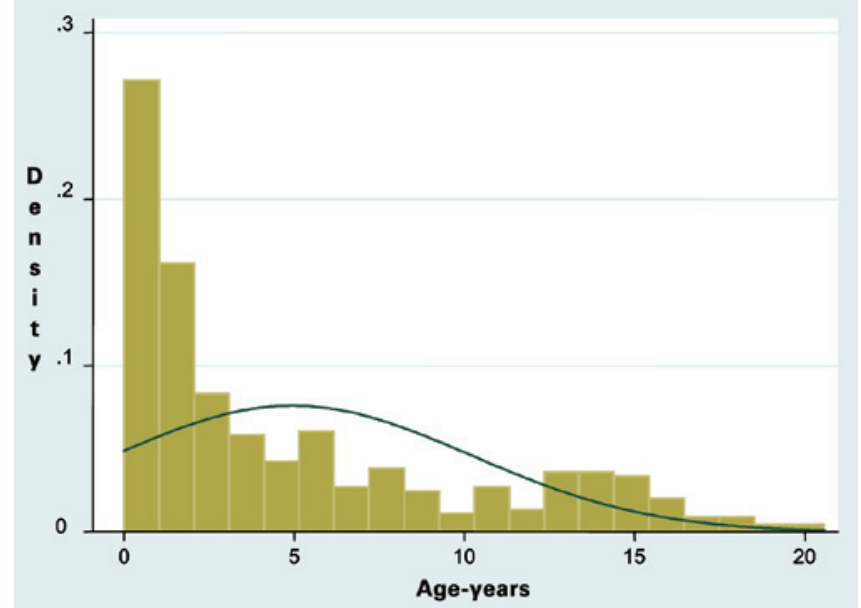

Figure 1. Histogram depicting the age (in years) of the inpatients

than 30 days, $21(75 \%)$ patients had been admitted due to clinical reasons, and the diseases most commonly associated with these prolonged hospitalizations were neoplasms $(32.14 \% ; \mathrm{p}=0.000)$.

Most patients were admitted due to clinical diagnoses. The reasons for hospitalization were similar between male and female patients $(\mathrm{p}=0.757)$, and these are listed in table 1 .

Table 1. Frequency distribution of reasons for hospitalization

\begin{tabular}{lcc}
\hline $\begin{array}{l}\text { Reason for } \\
\text { hospitalization }\end{array}$ & Frequency (\%) & $\begin{array}{c}\text { Cumulative } \\
\text { percentage (\%) }\end{array}$ \\
\hline Clinical & $328(75.75)$ & 75.75 \\
Surgical & $84(19.40)$ & 95.15 \\
Emergency & $7(1.62)$ & 96.77 \\
Birth & $10(2.31)$ & 99.08 \\
Transplant & $3(0.69)$ & 99.77 \\
Undisclosed & $1(0.23)$ & 100.00 \\
\hline
\end{tabular}

Respiratory conditions, congenital abnormalities, injuries, and poisoning were the causes of more than half of the hospitalizations. Neoplasms were the fourth leading cause of admission to intensive care $(8.08 \%)$, and cardiovascular diseases represented $1.62 \%$ of the total hospitalizations. There were no statistically significant differences between genders according to these diagnoses $(p=0.139)$ (Table 2).

The primary diagnoses were quantified, and pneumonia was the most common diagnosis for patients with respiratory diseases.

The three most common respiratory causes for hospitalization included bronchopneumonia, respiratory failure, and acute bronchitis. Traumatic brain injury accounted for $3.70 \%$ of the inpatients, and acute lymphoblastic leukemia was the most common neoplastic 
Table 2. Gender distribution of diagnoses grouped according to the ICD-10 chapters

\begin{tabular}{|c|c|c|c|c|}
\hline Diagnoses & $\begin{array}{c}\text { Female } \\
\mathrm{n}(\%)\end{array}$ & $\begin{array}{l}\text { Male } \\
\text { n (\%) }\end{array}$ & $\begin{array}{l}\text { Total } \\
\text { n (\%) }\end{array}$ & $\begin{array}{c}\text { Cumulative } \\
\text { frequency (\%) }\end{array}$ \\
\hline Respiratory system disorders & $62(43.06)$ & $82(56.94)$ & $144(33.26)$ & 33.26 \\
\hline Congenital malformations, deformations, and chromosomal abnormalities & $19(43.18)$ & $25(56.82)$ & $44(10.16)$ & 43.42 \\
\hline Injury, poisoning, and external causes & $25(59.52)$ & $17(40.48)$ & $42(9.7)$ & 53.12 \\
\hline Neoplasms & $14(40.00)$ & $21(60.00)$ & $35(8.08)$ & 61.20 \\
\hline Digestive system disorders & $15(44.12)$ & $19(55.88)$ & $34(7.85)$ & 69.05 \\
\hline Nervous system disorders & $8(26.67)$ & $22(73.33)$ & $30(6.93)$ & 75.98 \\
\hline Blood and blood-forming organ disorders & $15(71.43)$ & $6(28.57)$ & $21(4.85)$ & 80.83 \\
\hline Symptoms, signs, and abnormal findings not elsewhere classified & $11(55.00)$ & $9(45.00)$ & $20(4.62)$ & 85.45 \\
\hline Infectious and parasitic diseases & $9(52.94)$ & $8(47.06)$ & $17(3.93)$ & 89.38 \\
\hline Musculoskeletal system and connective tissue disorders & $3(27.27)$ & $8(72.73)$ & $11(2.54)$ & 91.92 \\
\hline Endocrine, nutritional, and metabolic disorders & $3(42.86)$ & $4(57.14)$ & $7(1.62)$ & 93.54 \\
\hline Circulatory system disorders & $1(14.29)$ & $6(85.71)$ & $7(1.62)$ & 95.16 \\
\hline Genitourinary system disorders & $4(57.14)$ & $3(42.86)$ & $7(1.62)$ & 96.78 \\
\hline Certain conditions originating in the perinatal period & $3(60.00)$ & $2(40.00)$ & $5(1.15)$ & 97.93 \\
\hline Skin and subcutaneous tissue disorders & $2(40.00)$ & $3(60.00)$ & $5(1.15)$ & 99.08 \\
\hline Mental and behavioral disorders & 0 & 1 & $1(0.23)$ & 99.31 \\
\hline Eye and adnexa disorders & 1 & 0 & $1(0.23)$ & 99.54 \\
\hline Ear and mastoid process disorders & 0 & 1 & $1(0.23)$ & 99.77 \\
\hline Factors influencing health status & 1 & 0 & $1(0.23)$ & 100.00 \\
\hline Total & $196(45.27)$ & $237(54.73)$ & 433 & \\
\hline
\end{tabular}

Table 3. Diagnoses of patients admitted to the Pediatric Intensive Care Center at Albert Einstein Israelite Hospital (ICD-10)

\begin{tabular}{|c|c|c|c|}
\hline Primary diagnoses & $\begin{array}{c}\text { Female } \\
\mathrm{n}(\%)\end{array}$ & $\begin{array}{l}\text { Male } \\
\text { n (\%) }\end{array}$ & $\begin{array}{l}\text { Total } \\
\text { n (\%) }\end{array}$ \\
\hline J18.0 - Bronchopneumonia, unspecified & $11(2.54)$ & $12(2.77)$ & $23(5.31)$ \\
\hline J96.9 - Respiratory failure, unspecified & $7(1.61)$ & $13(3.00)$ & $20(4.62)$ \\
\hline J21.9 - Acute bronchitis, unspecified & $5(1.15)$ & $14(3.23)$ & $19(4.39)$ \\
\hline S06.9 - Intracranial injury, unspecified & $10(2.31)$ & $6(1.39)$ & $16(3.70)$ \\
\hline J18.9 - Pneumonia, unspecified & $7(1.61)$ & $7(1.62)$ & $14(3.23)$ \\
\hline J98.0 - Diseases of bronchus, not elsewhere classified & $4(0.92)$ & $5(1.15)$ & $9(2.08)$ \\
\hline R56.8 - Other and unspecified convulsions & $5(1.15)$ & $4(0.92)$ & $9(2.08)$ \\
\hline C91.0 - Acute lymphoblastic leukemia & $5(1.15)$ & $3(0.69)$ & $8(1.85)$ \\
\hline J96.0 - Acute respiratory failure & $2(0.46)$ & $5(1.15)$ & $7(1.62)$ \\
\hline A09.0 - Diarrhea and unspecified gastroenteritis of infectious origin & $1(0.23)$ & $3(0.69)$ & $4(0.92)$ \\
\hline D80.1 - Nonfamilial hypogammaglobulinemia & $4(0.92)$ & 0 & $4(0.92)$ \\
\hline G93.2 - Benign intracranial hypertension & $1(0.23)$ & $3(0.69)$ & $4(0.92)$ \\
\hline G93.4 - Encephalopathy, unspecified & $1(0.23)$ & $3(0.69)$ & $4(0.92)$ \\
\hline J35.3 - Hypertrophy of tonsils with hypertrophy of adenoids & $3(0.69)$ & $1(0.23)$ & $4(0.92)$ \\
\hline K40.2 - Bilateral inguinal hernia, without obstruction or gangrene & $1(0.23)$ & $3(0.69)$ & $4(0.92)$ \\
\hline Others & $114(26.33)$ & $139(32.10)$ & $253(58.43)$ \\
\hline Total & 196 & 237 & 433 \\
\hline
\end{tabular}


cause for hospitalization, accounting for $1.85 \%$ of the inpatients (Table 3).

Of the 433 children who were admitted to the PICC during this period, 8 patients died $(1.85 \%$; 4 females and 4 males).

The average and median ages of the deceased patients were 8.9 and 8.5 years, respectively; the males had an average age $( \pm \mathrm{SD})$ of $8.5 \pm 3.7$ years, and the females had an average age of $9.3 \pm 6.4$ years $(p=0.2030)$.

The average length of stay for these 8 patients at the PICC was $48.86 \pm 57.48$ days, and this duration ranged from 2 days for a victim of traumatic brain injury to 161 days for a case of acute lymphoblastic leukemia. Of the 8 patients who died, 5 patients had remained in the PICC for more than 30 days, 2 patients had been admitted for up to 7 days, and 1 patient had been admitted for 14 days $(p=0.000)$.

Neoplasms and hematological diseases were present in 6 of the 8 deceased cases, as shown in table 4 .

Table 4. Frequency of deaths according to diagnostic group (ICD-10 chapters)

\begin{tabular}{lc}
\hline Diagnosis & $\begin{array}{c}\text { Frequency } \\
\mathbf{n}(\%)\end{array}$ \\
\hline Neoplasms & $4(50.0)$ \\
Diseases of the blood and blood-forming organs, & $2(25.0)$ \\
immune disorders & \\
Endocrine, nutritional, and metabolic diseases & $1(12.5)$ \\
Injuries, poisonings, and other consequences of external causes & $1(12.5)$ \\
\hline
\end{tabular}

The individual characteristics of each of the deceased patients are listed in table 5 .

Table 5. Characteristics of the deceased cases

\begin{tabular}{|c|c|c|c|c|}
\hline Gender & $\begin{array}{c}\text { Age } \\
\text { (years) }\end{array}$ & $\begin{array}{l}\text { Hospitalization } \\
\text { at PICC (days) }\end{array}$ & Diagnosis & Cause of death \\
\hline $\mathrm{F}$ & 16 & 14 & Aplastic anemia & Septic shock \\
\hline $\mathrm{F}$ & 8 & 2 & $\mathrm{TBI}$ & TBI gunshot wound \\
\hline M & 8 & 161 & $\begin{array}{c}\text { Acute lymphocytic } \\
\text { leukemia }\end{array}$ & Respiratory failure \\
\hline M & 9 & 37 & Adrenoleukodystrophy & Septic shock \\
\hline M & 4 & 6 & Medulloblastoma & Circulatory failure \\
\hline$M$ & 13 & 89 & $\begin{array}{c}\text { Acute myeloid } \\
\text { leukemia }\end{array}$ & $\begin{array}{l}\text { Multiple organ } \\
\text { failure }\end{array}$ \\
\hline $\mathrm{F}$ & 12 & 33 & $\begin{array}{c}\text { Acute lymphocytic } \\
\text { leukemia }\end{array}$ & $\begin{array}{l}\text { Multiple organ } \\
\text { dysfunction }\end{array}$ \\
\hline$F$ & 1 & 134 & $\begin{array}{c}\text { Acute lymphocytic } \\
\text { leukemia }\end{array}$ & $\begin{array}{l}\text { Severe combined } \\
\text { immunodeficiency, } \\
\text { respiratory failure, } \\
\text { renal failure }\end{array}$ \\
\hline
\end{tabular}

PICC: Pediatric Intensive Care Center; TBI: Traumatic brain injury.

\section{DISCUSSION}

ICUs play a vital role in the health care system. Onethird to half of all Americans will be admitted to an ICU at one point in their lives, and $20 \%$ of these patients typically succumb to their condition while admitted to these units. On average, ICUs contain $8 \%$ of the beds in a hospital, which represents $20 \%$ of the inpatients at the hospital. The expense of these units represents $0.9 \%$ of the economic activities in the United States, which is equivalent to $\$ 91$ million.

The characteristics of the inpatient population, their clinical conditions, and the circumstances in which deaths occur can assist ICUs with determining the required amount of resources, developing operating procedures, and training personnel. The goal of these strategic decisions is to improve the care provided to patients in ICUs by preventing deaths and minimizing patient suffering. To improve the performance of these units, a paradigm shift is required, whereby emphasis should be placed on the need to improve systems and processes rather than individual performance ${ }^{(11,12)}$. For the continuous pursuit of quality health care, the quantification of patient data is essential. Single indicators, such as mortality and length of hospital stay, do not indicate effectiveness unless the demographic and clinical characteristics of the inpatients are also known $^{(13)}$.

Approximately one-half of children in the UK admitted to PICUs are younger than 1 year of age, whereas the median age of patients at the PICC at HIAE was 2.7 years in 2009. Most children in the UK admitted to PICUs are hospitalized for less than 2 days, whereas $50 \%$ of the children who were admitted to the PICC were hospitalized for at least 35 days. From a report on PICUs in the UK, cardiovascular diseases were the most common reason for hospitalization, and these were followed in frequency by respiratory and neurological diseases. However, respiratory diseases were the most common reason for hospitalization among patients at the PICC at HIAE, followed by traumatic brain injury and neoplasms ${ }^{(7)}$. Chronic and degenerative diseases have become more frequent in Brazil, although the incidence of transmissible diseases also remains high ${ }^{(14)}$. Similar to studies by Alves et al. and Poongundran Namachivayam et al., this study observed a predominance of clinical patients in the PICC at $\operatorname{HIAE}^{(9,15)}$.

Infants and preschool-aged children between the ages of 1 and 4 years were most frequently admitted, which is similar to results found in previous studies ${ }^{(8-10,15-18)}$.

The overall mortality rate in the current study was $1.85 \%$, which is both lower $^{(8-9,15-19)}$ and similar ${ }^{(11)}$ to the 
rates reported in previous studies. Studies in the UK have documented a mortality rate of $11.1 \%$ for the period from 2001-2002(20), although more recent studies have reported mortality rates below $5 \%(11)$, and these differences emphasize the need for the collection of continuous and localized measurements. The average age of the patients who died at the PICC was 8.9 years, which is higher than that reported by Sands et al. (3.1 years of age), although the quartile in this study ranged from 0.61 to 10.6 years of age. Similar to the results of a study in the UK, neoplasms were the primary diagnosis for most of the children who died in the PICC ${ }^{(19)}$, whereas a study by Earle et al. found that pneumonia was the main cause of death among patients in PICUs in Mexico and Ecuador ${ }^{(18)}$.

This study analyzed the epidemiological data of patients who were admitted to the PICC at HIAE and compared these findings to those of other studies published in the literature. To compare the services provided by different PICUs, it is necessary to evaluate the characteristics of the services provided as well as those of the patients admitted to these units, including disease severity and epidemiological and demographic characteristics. Further studies in this line of research should be conducted because historical data can be used to identify local patterns of benefits or harm caused by interventions and new processes at PICUs. A secondary objective of future studies should be to assess whether additional data are needed to establish more accurate performance indicators for PICUs.

\section{CONCLUSION}

The data obtained in our study can be compared to those reported for other PICUs in Brazil and throughout the world, considering the epidemiological differences and the characteristics of the services provided. Additional data could also be combined with those collected in the PICC, and a historical series could then be created to ensure the continuous pursuit of health care quality.

\section{REFERENCES}

1. Fox JP, Hall CE, Elveback LR. Epidemiology: man and disease. London: MacMillan; 1970.

2. Rosenberg D, Handler A. Descriptive epidemiology and statistical estimation.
In: Rosenberg D, Monahan C, Handler A. Analytic methods in maternal and child health [Internet]. Chicago: University of Illinois; 1998 [cited 2010 Nov 2]. Available from: https://www.uic.edu/hsc/dscc/dataskills/magazine/ issues/current/ wrkbkpdfs/frontmatter.pdf

3. Barata RC. 0 desafio das doenças emergentes e a revalorização da epidemiologia descritiva. Rev Saúde Pública. 1997;31(5):531-7.

4. Werneck G. Epidemiologia descritiva: qualidade das informações e pesquisa nos serviços de saúde. Epidemiol Serv Saúde. 2009;18(3):205-7.

5. Lilienfeld AM, Lilienfeld DE. Foundations of epidemiology. New York: University Press; 1980.

6. Index Mundi. World infant mortality rate [Internet]. 2011 [cited 2011 Set 23]. Available from: http://www.indexmundi.com/world/infant mortality rate.html

7. Draper E, Lamming C, McKinney P, McShane P, Parslow R, Shearing A, et al. Annual report of the paediatric intensive care audit network. January 2007- December 2009 [Internet]. Leeds (UK): Universities of Leeds and Leicester; 2010 [cited 2011 Out 31]. Available from: http://www.picanet.org. uk/Documents/General/Annual\%20Report\%202010/2010\%20PICANet\%20 Annual\%20Report.pdf

8. Cutulo LR, Furtado Junior JR, Botelho L. Perfil dos pacientes internados na unidade de terapia intensiva pediátrica do hospital infantil Joana de Gusmão no ano de 1993. ACM Arq Catarin Med. 1994;23(2):95-100.

9. Alves MJ, Alves MV, Bastos HD. Validação do uso de escores preditivos em uma unidade de terapia intensiva pediátrica do Brasil. Rev Bras Ter Intensiva. 2000;12(1):36-43.

10. Einloft PR, Garcia PC, Piva JP, Bruno F, Kipper DJ, Fiori RM. Perfil epidemiológico de dezesseis anos de uma unidade de terapia intensiva pediátrica I. Rev Saúde Pública. 2002;36(6):728-33.

11. National Center for Health Statistics. Health, United States, 2010: with special feature on death and dying. Hyattsville (MD): National Center for Health Statistics; 2011

12. Garland A. Improving the ICU: Part 1. Chest. 2005;127(6):2151-64.

13. McMillan TR, Hyzy RC. Bringing quality improvement into the intensive care unit. Crit Care Med. 2007;35(2 Suppl):S59-65.

14. Schramm JM, de Oliveira AF, Leite IC, Valente JG, Gadelha AM, Portela MC, et al. Transição epidemiológica e o estudo de carga de doença no Brasil. Ciênc Saúde Coletiva [Internet]. 2004 [citado 2012 Feb 24] 10;9(4):897908. Disponível em: http://www.saude.es.gov.br/download/TRANSICAO EPIDEMIOLOGICA E CARGA DE DOENCA NO BRASIL.pdf

15. Namachivayam P, Shann F, Shekerdemian L, Taylor A, van Sloten I, Delpozzo $C$, et al. Three decades of pediatric intensive care: who was admitted, what happened in intensive care, and what happened afterward. Pediatr Crit Care Med. 2010;11(5):549-55.

16. Gemke RJ, Bonsel GJ, van Vught AJ. Effectiveness and efficiency of a Dutch pediatric intensive care unit: validity and application of the pediatric risk of mortality score. Crit Care Med. 1994;22(9):1477-84.

17. Bertolini G, Ripamonti D, Cattaneo A, Apolone G. Pediatric risk of mortality: an assessment of its performance in a sample of 26 Italian intensive care units. Crit Care Med. 1998;26(8):1427-32.

18. Earle M Jr, Martinez Natera O, Zaslavsky A, Quinones E, Carrillo H, Garcia Gonzalez $E$, et al. Outcome of pediatric intensive care at six centers in Mexico and Ecuador. Crit Care Med. 1997;25(9):1462-7.

19. Sands R, Manning JC, Vyas H, Rashid A. Characteristics of deaths in paediatric intensive care: a 10 - year study. Nurs Crit Care. 2009;14(5):235-40.

20. Jones S, Rantell K, Stevens K, Colwell B, Ratcliffe JR, Holland P, et al. Outcome at 6 months after admission for pediatric intensive care: a report of a national study of pediatric intensive care units in the United Kingdom. Pediatrics. 2006;118(5):2101-8. 